\title{
Effect of Blends Gasoline with Oxygenated Additives in the Performance of Internal Combustion Engine
}

\author{
Suzara Rayanne de Castro Sena*, André Luis Oliveira de Almeida, Leonara Luizza da Costa Leite, \\ Jean Gustavo de Melo Araujo, Eduardo Lins de Barros Neto, Camila Gambini Pereira
}

Centre of Education and Research in Oil and Gas, Federal University of Rio Grande do Norte (UFRN), Natal, Brazil

Email: *suzararayanne@hotmail.com

How to cite this paper: de Castro Sena S.R., de Almeida, A.L.O., da Costa Leite, L.L., de Melo Araujo, J.G., de Barros Neto, E.L. and Pereira, C.G. (2021) Effect of Blends Gasoline with Oxygenated Additives in the Performance of Internal Combustion Engine. Journal of Power and Energy Engineering, 9, 1-9.

https://doi.org/10.4236/jpee.2021.97001

Received: June 14, 2021

Accepted: July 13, 2021

Published: July 16, 2021

Copyright $\odot 2021$ by author(s) and Scientific Research Publishing Inc. This work is licensed under the Creative Commons Attribution International License (CC BY 4.0).

http://creativecommons.org/licenses/by/4.0/

(c) (i) Open Access

\begin{abstract}
The objective of this study was to evaluate the effect of blends of different oxygenated additives on gasoline in SI engine Otto cycle. The formulations analyzed were: pure gasoline (type $\mathrm{A}$ ), common gasoline (type $\mathrm{C}$ ), gasoline type $\mathrm{A}+15 \%(\mathrm{v} / \mathrm{v})$ oxygenated additives (ethanol, ethyl octanoate, ethyl oleate). The experiments were performed using engine Branco 4-stroke and 2-cylinder, electric dynamometer, exhaust system, control unit composed of Multi-K unit, variable selector and load cell, stroboscope tachometer, fuel supply system and stopwatch. The rotation was conserved at $4400 \mathrm{rpm}$ and wheel power varied from $3 \mathrm{~kW}$ to $12 \mathrm{~kW}$, with intervals of $3 \mathrm{~kW}$ to obtain hourly consumption curves and brake specific fuel consumption. Even esters and ethanol having lower heat of combustion, hourly consumption was similar to pure gasoline (type A). In relation to the brake specific fuel consumption, increasing the wheel power had a better conversion of the mass of fuel burned into energy. Thus, this study showed that the mixture of gasoline and esters (ethyl octanoate and ethyl oleate) presented good efficiency in terms of consumption. This research contributes to the needs and to the current studies in which industries started to add renewable products to petroleumderived fuels; in order to obtain more sustainable fuels at lower costs.
\end{abstract}

\section{Keywords}

Gasoline, Oxygenated Additives, Consumption

\section{Introduction}

Fuel is a material whose burning is used to produce heat, energy, or light. Its 
importance is accompanied by the evolutionary process of man, the heat energy of the sun being the source that originated all the others. The production and consumption of fuels have increased in recent years associated with population, economic and technological growth. Petroleum still represents the most significant part in the amount of world fuel consumption, standing out with energy sources such as coal, natural gas, biofuels, and electricity [1]. Among the commonly used vehicular fuels are gasoline, diesel, natural gas, ethanol, and biodiesel.

The petroleum fraction with the highest commercial value is gasoline, and the main processes used for its production are: distillation, cracking, hydrocracking, reforming, alkylation, polymerization, and isomerization. The gasoline composition is complex comprising hydrocarbons ranging from four to twelve carbon atoms, typically having hydrocarbons of five and eight carbon, and having boiling points between $38^{\circ} \mathrm{C}$ and $205^{\circ} \mathrm{C}$ [2] [3].

With the emergence of cheaper and sustainable fuels, industries started to add non-oil products to gasoline and diesel, such as ethanol in gasoline and biodiesel in diesel. With the ban on tetraethyl lead as an additive in gasoline due to its toxic and carcinogenic effects, oxygenated compounds have become an alternative to add positive environmental and performance aspects to gasoline. Currently, the most used oxygenated compounds correspond to aliphatic alcohols and ethers containing one to six carbon atoms [4] [5].

The mixture of fuels aims to improve different aspects from the environmental and economic points of view. For example, the common gasoline in Brazil (type $\mathrm{C}$ ) is the fuel obtained from the mixture of gasoline and anhydrous ethyl alcohol, in the proportions defined by current legislation, currently $27 \%$, v/v [6]. The use of alcohol as fuel and in mixture with gasoline was stimulated in the 1970s with the petroleum crisis. Then, alcohol emerged as an alternative fuel to reduce dependence on fossil fuels. Its application is encouraged by presenting affordable price, be obtained from renewable sources and its burning emit less polluting compounds when compared to fossil fuels [7] [8] [9]. However, ethanol presents disadvantages such as low calorific value, high volatility, high solubility in water being conducive to contamination with the water content in the atmosphere. Rovai [10] reported from measures of lubricity in blends of ethanol and gasoline that the lubricity of the blend decreases with increasing alcohol content in the blend. The addition of ethanol to diesel shows a similar effect, which may reduce lubricity and create potential wear problems in fuel pumps as described by Li et al. [11].

The quality of gasoline is related to the use of additives, which are fundamental for its better use and commercialization. Still, with the advent of flex-fuel engines, the study of performance of fuels and mixtures becomes very relevant. Oxygenated compounds such as ethyl octanoate and ethyl oleate added to gasoline showed good fuel properties [12], as well as a promising prospect of improving the lubricity of gasoline, which influences the reduction of friction and wear of the engine [13]. Thus, the objective of this study was to evaluate the hourly consumption and brake specific fuel consumption of formulations con- 
taining gasoline + oxygenated additives, in SI engine Otto cycle, considering as additives: ethanol, ethyl octanoate, and ethyl oleate added $15 \% \mathrm{v} / \mathrm{v}$ in the mixture, in order to compare the application of new oxygenated additives with ethanol that is widely used in gasoline blending in several countries.

\section{Method}

\subsection{Ester Synthesis and Chromatographic Analysis}

The esters, ethyl octanoate and ethyl oleate, were obtained by esterification reaction. The reaction conditions were: 1:3 fatty acid and ethanol (Synth, lot 190231, P.A.) molar ratio, $\mathrm{H}_{2} \mathrm{SO}_{4}$ catalyst (Sigma Aldrich, lot SZBE2260V) with $1 \%$ of the fatty acid mass, temperature of $80^{\circ} \mathrm{C}$ and time of 60 minutes. After the reaction, the product went through solvent extraction (water), chemically active extraction with $0.01 \mathrm{M}$ sodium bicarbonate solution (Êxodo Científica, lot BS8763KA), adsorption of traces of water by adding anhydrous sodium sulfate (Dinâmica Química Contemporânea, lot 55937) and filtration [14] [15].

The esters were evaluated by gas chromatography analysis (Shimadzu, model GC-2010) coupled to mass spectrometer (Shimadzu, model QP 2010). A $30 \mathrm{~m}$ long, $2.3 \times 10^{-7} \mathrm{~m}$ thick CP8751 column with $2.5 \times 10^{-4} \mathrm{~m}$ internal diameter was used. Column temperature was programmed from $150^{\circ} \mathrm{C}$ to $250^{\circ} \mathrm{C}$. Helium was used as carrier gas at a constant pressure of $1.105 \mathrm{kPa}$ and flow of $1.08 \times 10^{-6} \mathrm{~m}^{3}$ per minute.

\subsection{Fuel Consumption}

The tests were done on a 4-stroke gasoline engine whose specifications, according to the instruction manual, are shown in Table 1.

Fuels analyzed: pure gasoline-type A (GAS A), common gasoline-type C (GAS C), gasoline type A + ethyl octanoate $15 \% \mathrm{v} / \mathrm{v}$ (OC 15), gasoline type A + ethyl oleate $15 \% \mathrm{v} / \mathrm{v}$ (OL 15).

The engine was coupled to an electric dynamometer (Kohlbach, 112MB) equipped with a load control cabinet. Tachometer (Instrutemp, ST-707) was used to check

Table 1. Engine specifications [16].

\begin{tabular}{cc}
\hline Manufacturer & Branco \\
Model & B4T-20.0 H \\
Type & Gasoline engine, 4 -stroke, 2-cylinder \\
Maximum power & $20 \mathrm{cv}$ a $3600 \mathrm{rpm}$ \\
Rated power & $18 \mathrm{cv}$ a $3600 \mathrm{rpm}$ \\
Maximum torque $(\mathrm{kgfm} / \mathrm{rpm})$ & $3.8 / 2500$ \\
Cylinder volume $\left(\mathrm{cm}^{3}\right)$ & 614 \\
Compression ratio & $8.3: 1$ \\
Bore and stroke $(\mathrm{mm})$ & $77 \times 66$ \\
Ignition & Electronic \\
\hline
\end{tabular}


the engine speed. Fuel consumption was measured using burettes and a stopwatch. Before analyzing a new formulation, the engine ran long enough with an amount of the new formulation to ensure that the formulation analyzed earlier did not interfere with the next result [17] [18].

To perform the tests, the engine was maintained at full load as a function of the rotation. The rotation was conserved at $4400 \mathrm{rpm}$ and power was varied from $3 \mathrm{~kW}$ to $12 \mathrm{~kW}$, with intervals of $3 \mathrm{~kW}$ to obtain fuel consumption curves. Figure 1 shows a schematic drawing of the experimental apparatus used.

Initially, the motor was started with zero load for 20 minutes for stabilization. After this period the rotation was adjusted to $4400 \mathrm{rpm}$ with the aid of a stroboscopic tachometer. With the load at $3 \mathrm{~kW}$, the consumption analysis was started by measuring the time required for the engine to consume a quantity of $50 \mathrm{~mL}$ of the fuel, and the time was timed for every $5 \mathrm{~mL}$ of consumption. The consumption in the engine was also analyzed in loads of 6,9 and $12 \mathrm{~kW}$, for each formulation arranged in the burettes.

The fuel consumption was determined by measuring the amount of fuel consumed per unit of time, according to Equation (1) [19].

$$
C=\left(3600 \times \rho_{i} \times v\right) / t
$$

where:

$C$ : consumption $(\mathrm{g} / \mathrm{h})$;

$\rho_{i}$ : fuel density $\left(\mathrm{g} / \mathrm{cm}^{3}\right)$;

$v$. volume of fuel consumed $(\mathrm{mL})$;

$t$. fuel consumption time (s).

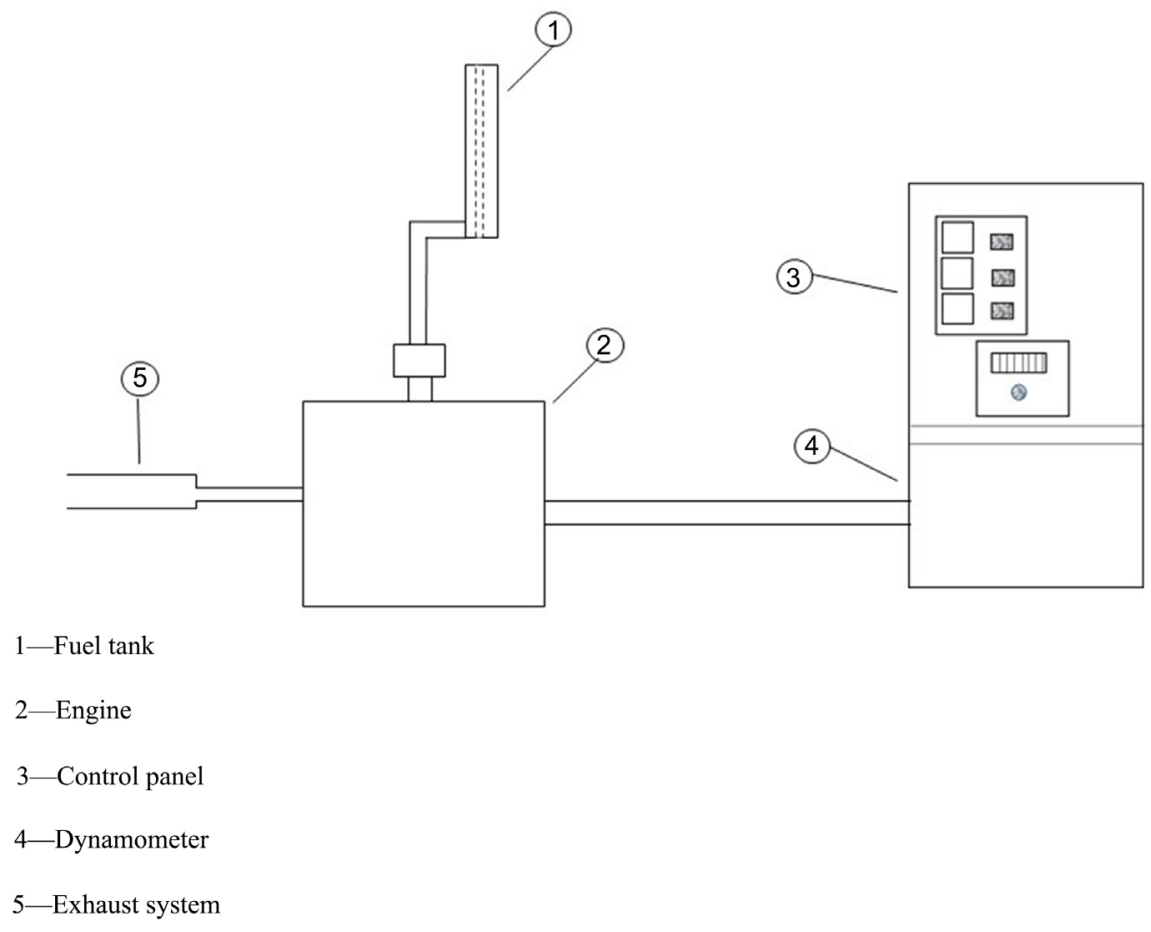

Figure 1. The schematic of experimental setup. 
The brake specific fuel consumption was estimated through Equation (2) [19] being defined as the relation between fuel consumption and power.

$$
\mathrm{BSFC}=C / P
$$

where:

BSFC: brake specific fuel consumption $(\mathrm{g} / \mathrm{kW} \cdot \mathrm{h})$;

C: consumption $(\mathrm{g} / \mathrm{h})$;

$P$ : power $(\mathrm{kW})$.

\section{Analysis and Discussion of Results}

\subsection{Chromatographic Analysis of the Esters}

The esters were evaluated by gas chromatography coupled to mass spectrometer. Figure 2 and Figure 3 show the chromatograms of ethyl octanoate and ethyl oleate, showing the different retention times that each compound elutes, where the esters were detected and identified.

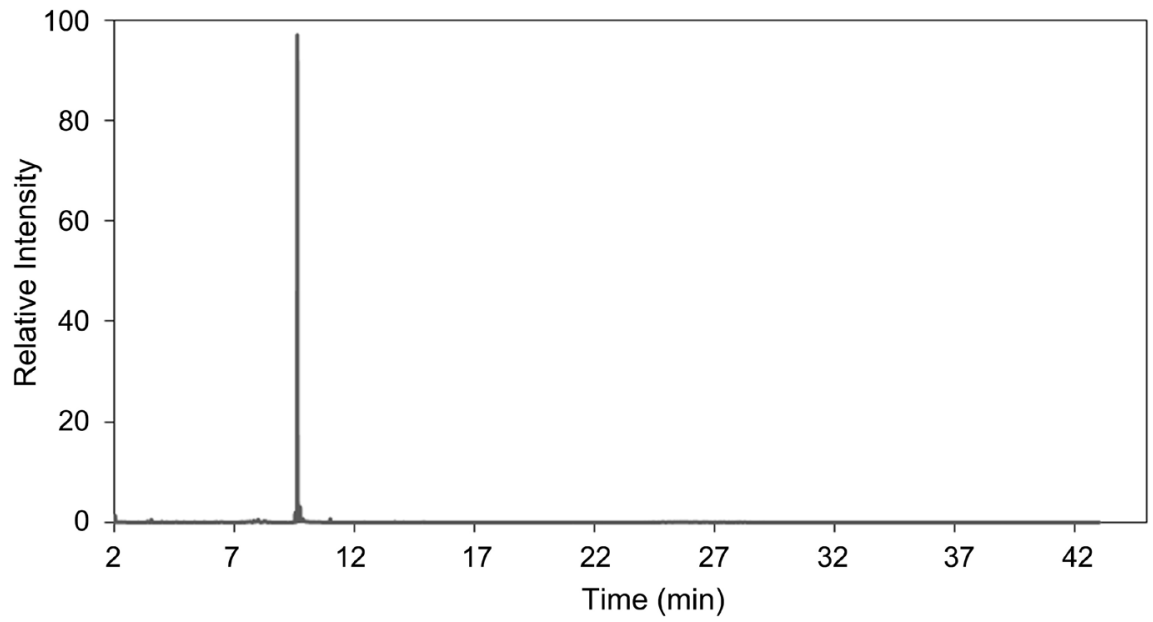

Figure 2. Chromatogram of ethyl octanoate.

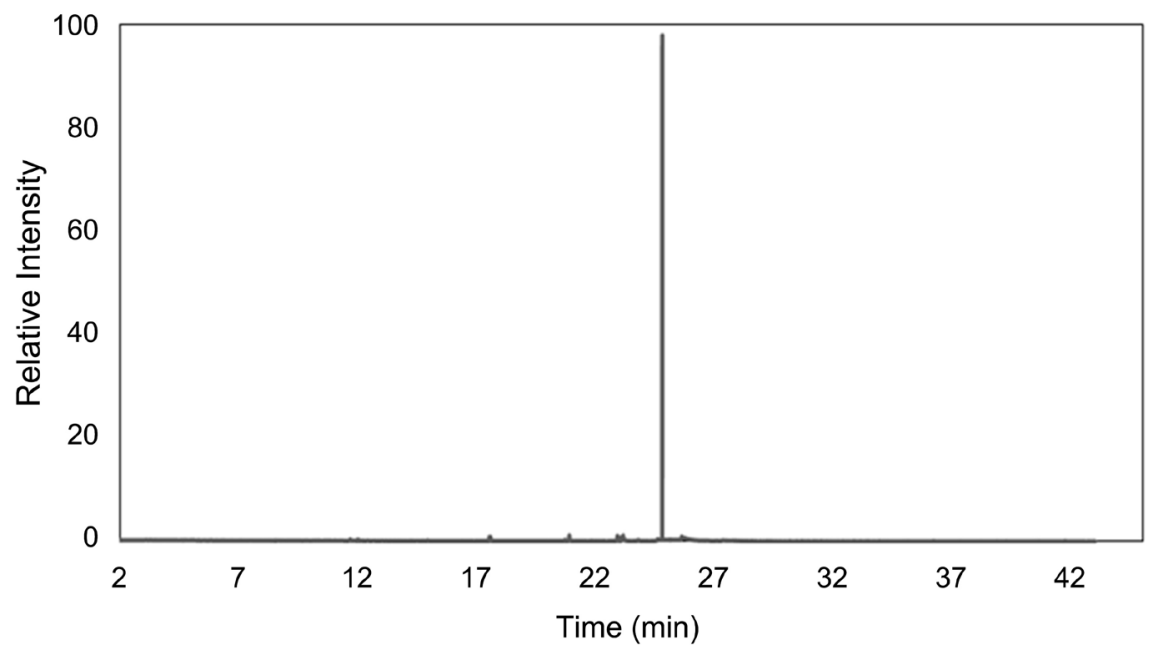

Figure 3. Chromatogram of ethyl oleate. 
Figure 2 and Figure 3 evidence the good degree of purity of the esters, these esters being the results of the esterification reaction with conversion from $97 \%$ to ethyl octanoate and $98 \%$ to ethyl oleate. For esterification reactions following the methodology described, the yield of ethyl octanoate was $92 \%$ and the yield in ethyl oleate was $93 \%$.

\subsection{Consumption in SI Engine}

Figure 4 shows the results of the analyzed for the consumption of the fuels in the engine.

It can be seen from Figure 4 that the consumption of the formulations increases as the power dissipated by the engine increases. Even esters having lower heat of combustion, hourly consumptions for the mixtures containing these additives were similar to pure gasoline (GAS A) and gasoline with ethanol (GAS C). Although the consumption of the same volume of each sample has been analyzed, the formulation with the highest density favors a lower consumption, since a unit of mass greater per volume enters the combustion chamber, as occurs in formulations containing the esters.

The brake specific fuel consumption of the formulations analyzed is shown in Figure 5.

As shown in Figure 5, it was verified that the brake specific fuel consumption decreases with the increase of power, for all formulations analyzed, in which the BSFC relates the mass flow of fuel that the motor consumes and the effective power, being a measure of the efficiency of the engine. Thus, at $12 \mathrm{~kW}$ power the engine requires a smaller amount of fuel to produce $1 \mathrm{KW}$ than at lower power, as shown in Figure 5 in that by increasing power a better conversion of the mass of fuel burned in energy. Also, regarding the brake specific fuel consumption curves, it was noticed that as the power increases the difference of specific consumption between the formulations decreases.

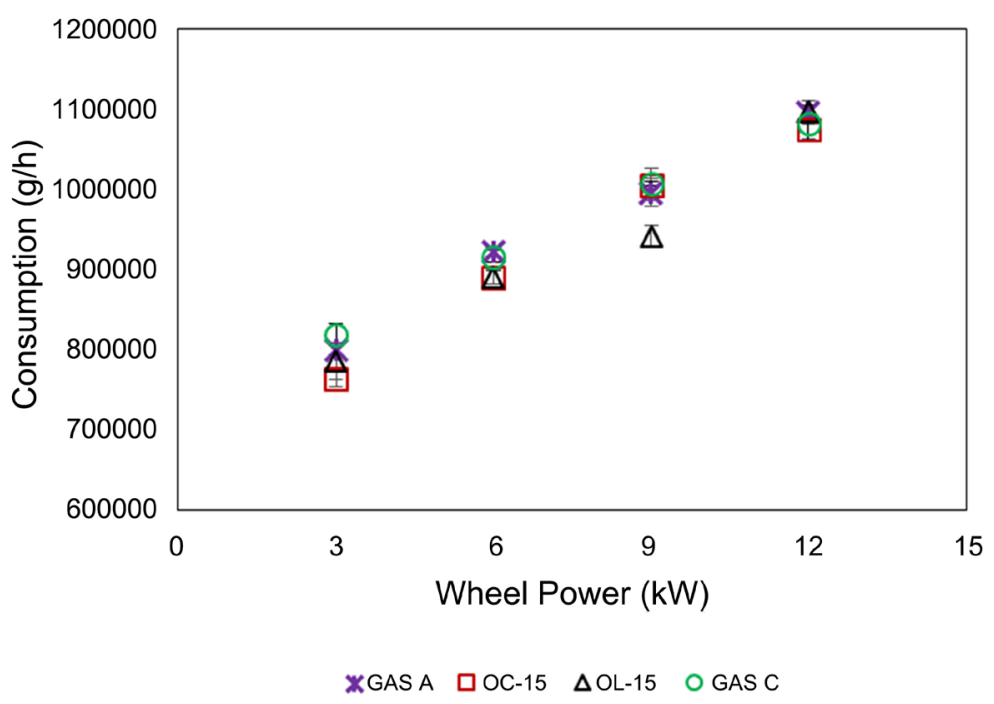

Figure 4. Consumption for formulations containing gasoline and ester. 


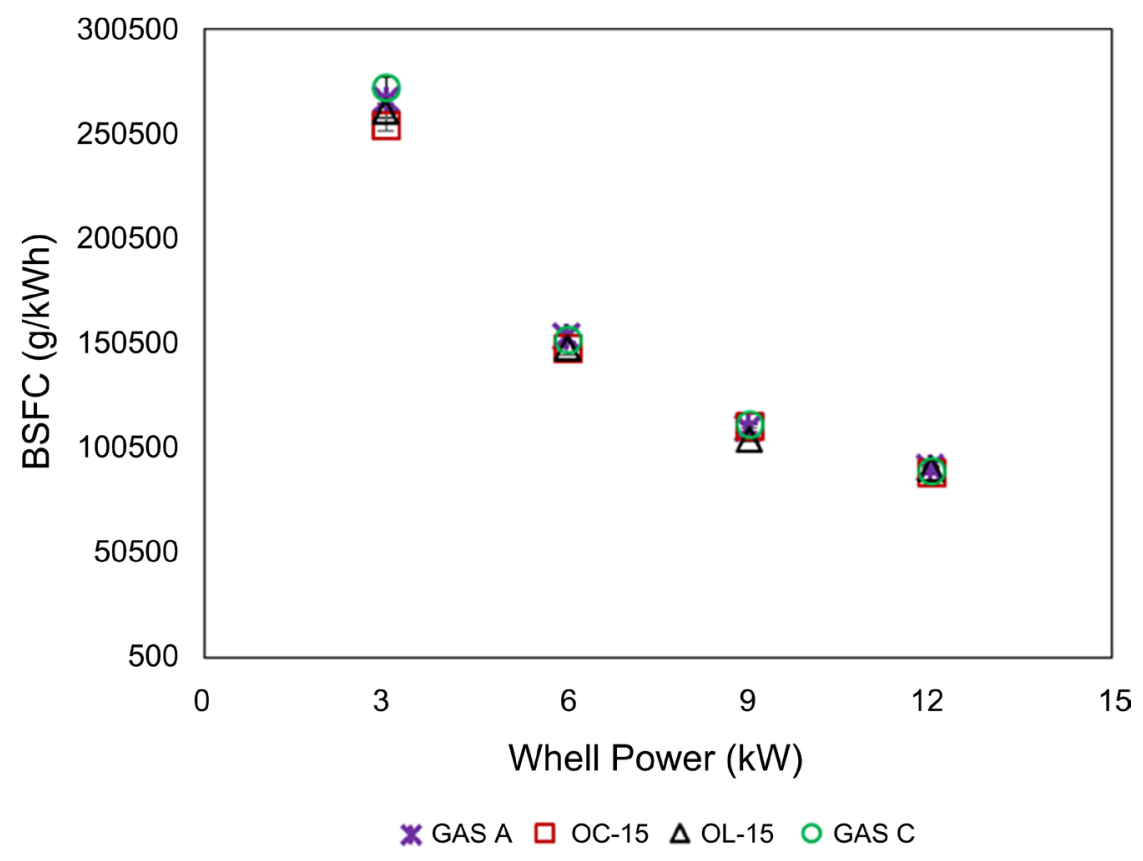

Figure 5. Brake specific fuel consumption for formulations containing gasoline and ester.

The results are very relevant and show the compatibility of ethyl octanoate and ethyl oleate as additive to gasoline in terms of engine performance. In addition to alcohol and ethers, esters have also been highlighted as additives. Wang et al. [20] reported that 3-Hydroxybutyrate methyl ester when mixed with gasoline, its performance was similar or superior to that of gasoline mixed with ethanol in terms of oxygen content, dynamic viscosity, flash point and boiling point. Jenkins et al. [21] evaluated mono and diesters for their potential as a substitute for aviation kerosene, mineral diesel or gasoline. Pelaez-Samaniego et al. [22] evaluated the use of gasoline and "bioflex" (a mixture of carboxylic esters from pyrolysis oil) in an Otto engine. Power and fuel consumption were statistically similar for type A gasoline, type $\mathrm{C}$ gasoline and mixtures of $10 \%$ by volume of bioflex with type $\mathrm{C}$ gasoline. As well as other oxygenates, ethyl octanoate and ethyl oleate, appear as an important alternative to be used as an additive.

\section{Conclusions}

This study evaluated the influence of two types of ethyl esters, ethyl octanoate and ethyl oleate, in the additive of gasoline based on fuel consumption analysis in Otto cycle engine. Even esters having lower heat of combustion, consumption was similar to pure gasoline and gasoline with ethanol. The brake specific fuel consumption also showed that the blends containing the esters showed efficiency similar to that of pure gasoline (GAS A) and gasoline with ethanol (GAS C).

Therefore, the consumption curves obtained in the Otto cycle engine showed that, regardless of the type of fuel, efficiency does not change, showing a promising result for the application of ethyl octanoate and ethyl oleate as a gasoline additive. 


\section{Acknowledgements}

The authors are grateful to CNPQ and PPGEQ/DEQ/UFRN for their financial support.

\section{Conflicts of Interest}

The authors declare no conflicts of interest regarding the publication of this paper.

\section{References}

[1] IEA (2014) Key World Energy Statistics. Internacional Energy Agency. https://www.oecd-ilibrary.org/energy/key-world-energy-statistics-2014_key_energ stat-2014-en;jsessionid=UyE0R76K7HOCxMUkQY-L_-Hf.ip-10-240-5-49

[2] Szklo, A.S., Uller, V.C. and Bonfá, M.H.P. (2012) Fundamentos do refino de petróleo: Tecnologia e economia. Interciência, Rio de Janeiro.

[3] Cardoso, L.C. (2012) Petróleo: do poço ao posto. Qualitymark Editora, Rio de Janeiro.

[4] Lob, A., Buenafe, R. and Nurredin, M.A. (1998) Determination of Oxygenates in Gasoline by FTIR. Fuel, 77, 1861-1864. https://doi.org/10.1016/S0016-2361(98)00103-3

[5] Menezes, E.W., Cataluña, R., Samios, D. and Silva, R. (2006) Addition of an Azeotropic ETBE/Ethanol Mixture in Eurosuper-Type Gasolines. Fuel, 85, 2567-2577. https://doi.org/10.1016/j.fuel.2006.04.014

[6] MAPA (2015) Ministério da Agricultura, Pecuária e Abastecimento. Diário Oficial da União, Portaria N. 75, 05 de março de 2015, Brasil.

[7] Canakci, M., Ozsezen, N.A., Alptekin, E. and Eyidogan, M. (2013) Impact of Alcoholegasoline Fuel Blends on the Exhaust Emission of an SI Engine. Renewable Energy, 52, 111-117. https://doi.org/10.1016/j.renene.2012.09.062

[8] Clark, C.R., Dutcher, J.S., McClellan, R.O., Naman, T.M. and Seizinger, D.E. (1983) Influence of Ethanol and Methanol Gasoline Blends on the Mutagenicity of Particulate Exhaust Extracts. Archives of Environmental Contamination and Toxicology, 12, 311-317. https://doi.org/10.1007/BF01059408

[9] Koç, M., Sekmen, Y., Topgül, T. and Yücesu, H.S. (2009) The Effects of EthanolUnleaded Gasoline Blends on Engine Performance and Exhaust Emissions in a Sparkignition Engine. Renewable Energy, 34, 2101-2106. https://doi.org/10.1016/j.renene.2009.01.018

[10] Rovai, F.F. (2005) Desgaste e corrosão de bombas de combustível com misturas de álcool e gasohol. Master Thesis, Escola Politécnica da Universidade de São Paulo, São Paulo.

[11] Li, D.G., Zhen, H., Lŭ, X.C., Zhang, W.-G. and Yang, J.-G. (2005) Physico-Chemical Properties of Ethanol-Diesel Blend Fuel and Its Effect on Performance and Emissions of Diesel Engines. Renewable Energy, 30, 967-976.

https://doi.org/10.1016/j.renene.2004.07.010

[12] Sena, S.R.C., Barros Neto, E.L. and Pereira, C.G. (2019) Effect of Ethyl Octanoate and Ethyl Oleate on the Properties of Gasoline Fuel Mixture. Energy Fuels, 33, 9429-9436. https://doi.org/10.1021/acs.energyfuels.9b01282

[13] Sena, S.R.C., Barros Neto, E.L., Pereira, C.G. (2019) Evaluation of the Lubrication of Ethyl Oleate and Ethyl Octanoate as Gasoline Additive. Brazilian Journal of Petro- 
leum and Gas, 13, 111-118. https://doi.org/10.5419/bjpg2019-0011

[14] Nicolau, A., Mariath, R.M., Martini, E.A., Martini, D.S. and Samios, D. (2010) The Polymerization Products of Epoxidized Oleic Acid and Epoxidized Methyl Oleate with cis-1,2-cyclohexanedicarboxylic Anhydride and Triethylamine as the Initiator: Chemical Structures, Thermal and Electrical Properties. Materials Science and Engineering, 30, 951-962. https://doi.org/10.1016/j.msec.2010.04.014

[15] Vogel, A.I. (1986) Química Orgânica. Editora da Universidade de São Paulo, São Paulo.

[16] Branco. Manual de instruções. Motor B4T-20.0 H. https://www.branco.com.br/la/pt_br/suporte/manuais.html

[17] Fernandes, M.R. (2011) Formulação de novos combustíveis base diesel: Avaliação de desempenho e emissões. Ph.D. Thesis, Universidade Federal do Rio Grande do Norte, Natal.

[18] Uchôa, I.M.A. (2015) Combustíveis base diesel microemulsionados com glicerina: formulação e avaliação de desempenho. Master Thesis, Universidade Federal do Rio Grande do Norte, Natal.

[19] Dantas Neto, A.A., Fernandes, M.R., Barros Neto, E.L., Castro Dantas, T.N. and Moura, M.C.P.A. (2011) Alternative Fuels Composed by Blends of Nonionic Surfactant with Diesel and Water: Engine Performance and Emissions. Brazilian Journal of Chemical Engineering, 28, 521-531. https://doi.org/10.1590/S0104-66322011000300017

[20] Wang, S.Y., Wang, Z., Liu, M.M., Xu, Y., Zhang, X.J. and Chen, G.Q. (2010) Properties of a New Gasoline Oxygenate Blend Component: 3-Hydroxybutyrate Methyl ester Produced from Bacterial Poly-3-Hydroxybutyrate. Biomass and Bioenergy, 34, 1216-1222. https://doi.org/10.1016/j.biombioe.2010.03.020

[21] Jenkins, R.W., Munro, M., Nash, S. and Chuck, C. J. (2013) Potential Renewable Oxygenated Biofuels for the Aviation and Road Transport Sectors. Fuel, 103, 593 599. https://doi.org/10.1016/j.fuel.2012.08.019

[22] Pelaez-Samaniego, M.R., Mesa-Pérez, J., Cortez, L.A.B., Rocha, J.D., Sanchez, C.G. and Marín, H. (2011) Use of Blends of Gasoline with Biomass Pyrolysis-Oil Derived Fractions as Fuels in an Otto Engine. Energy for Sustainable Development, 15, 376-381. https://doi.org/10.1016/j.esd.2011.06.001 